\title{
Melatonin and its metabolites as anti-nitrosating and anti-nitrating agents
}

\author{
Rudiger Hardeland \\ University of Gottingen, Johann Friedrich Blumenbach Institute of Zoology and Anthropology, Gottingen, \\ Germany.
}

\begin{abstract}
Although basal and moderately elevated levels of nitric oxide are physiologically necessary and beneficial, excessive upregulations of this signaling molecule can be a cause of damage and cellular dysfunctions. In the presence of increased amounts of superoxide anions $\left(\cdot \mathrm{O}_{2}^{-}\right)$and carbon dioxide, peroxynitrite $\left(\mathrm{ONOO}^{-}\right)$and the peroxynitrite- $\mathrm{CO}_{2}$ adduct $\left(\mathrm{ONOOCO}{ }_{2}^{-}\right)$generate hydroxyl $(\cdot \mathrm{OH})$, nitrogen dioxide $\left(\cdot \mathrm{NO}_{2}\right)$ and carbonate $\left(\cdot \mathrm{CO}_{3}{ }^{-}\right)$radicals, which damage biomolecules by oxidation/peroxidation, nitration and nitrosation reactions. Nitrosation also occurs with all three NO congeners $\left(\mathrm{NO}^{+}, \cdot \mathrm{NO}\right.$, and $\mathrm{HNO}=$ protonated $\left.\mathrm{NO}^{-}\right)$, with $\cdot \mathrm{NO}$ especially in combination with electron/hydrogen-abstracting compounds, or with $\mathrm{N}_{2} \mathrm{O}_{3}$.

3-Nitrotyrosine, found in low-density lipoprotein particles (LDL), atherosclerotic plaques, ion channels, receptors, transporters, enzymes and respirasomal subunits, is associated with numerous dysfunctions. Damage to the mitochondrial electron transport chain (ETC) is of particular significance and involves nitration, nitrosation and oxidation of proteins, cardiolipin peroxidation, and binding of $\bullet \mathrm{NO}$ to ETC irons. Resulting bottlenecks of electron flux cause enhanced electron leakage which leads to elevated $\bullet \mathrm{O}_{2}{ }^{-}$. In combination with high $\cdot \mathrm{NO}, \cdot \mathrm{O}_{2}^{-}$initiates a vicious cycle by generating more peroxynitrite that leads to further blockades and electron dissipation. Mitochondrial dysfunction, as induced via the $\bullet \mathrm{NO} /$ peroxynitrite pathway, is of utmost importance in inflammatory diseases, especially sepsis, but also relevant to neurodegenerative and various other disorders. It may contribute to processes of aging.

Melatonin, hormone of the pineal gland and product of other organs, interacts directly with reactive nitrogen species, but, more importantly, has antiinflammatory properties and downregulates inducible and neuronal NO synthases (iNOS, nNOS). It does not block moderately elevated $\bullet \mathrm{NO}$ formation, but rather blunts excessive rises as occurring in sepsis and breaks the vicious cycle of mitochondrial electron leakage. The melatonin metabolite $N^{1}$-acetyl-5-methoxykynuramine (AMK) forms stable nitrosation products and efficiently inhibits iNOS and nNOS, in conjunction with other antiinflammatory properties.
\end{abstract}

Key words:

Kynuramines; Melatonin;

Mitochondria; Nitration;

Nitrosation; Reactive nitrogen

\section{Correspondence:}

R. Hardeland

Universität Gottingen,

Johann Friedrich Blumenbach Institut für Zoologie und Anthropologie,

Berliner Str. 28,

37073 Gottingen, Germany.

rhardel@gwdg.de

Received: July 19, 2010

Accepted: November 8, 2010

Published online: December 11, 2010

J Exp Integr Med 2011; 1:67-81

DOI:10.5455/jeim.111210.ir.003

\section{Introduction}

The indoleamine melatonin ( $N$-acetyl-5methoxytryptamine; Fig.1), once discovered as a pineal hormone with skin lightening properties in fish and amphibia, later identified as a major regulator of seasonal and circadian rhythms, is now known to represent a highly pleiotropic compound produced in various tissues and exerting numerous, highly divergent effects $[1,2]$. This remarkable diversity appears to be the consequence of a progressive gain of functions, from a primary, ancient protection against reactive intermediates [3, 4] to the more recently acquired regulation of circadian, immunological, reproductive and neurobiological mechanisms [4] that have ended up, in vertebrates, in an orchestrating, highly versatile role [5]. Therefore, it seems important to perceive melatonin neither only in its chronobiotic function nor simply as a radical scavenger, but rather as a compound acting in a complex manner at different levels of integration.

As will be outlined in this review, part of this complexity is reflected by melatonin's multiple interactions with reactive nitrogen species (RNS). This comprises chemical reactions with various nitrogen-containing compounds and regulatory influences as well, at the levels of organelles, especially mitochondria, of cells and tissues. These control mechanisms are also of considerable pathophysiological interest. Moreover, melatonin should be seen in relation to its metabolites. Especially one of its kynuramine derivatives, $N^{1}$ acetyl-5-methoxykynuramine (AMK; Fig.1), displays properties as a potent regulator and scavenger of nitric oxide (NO) [6]. 


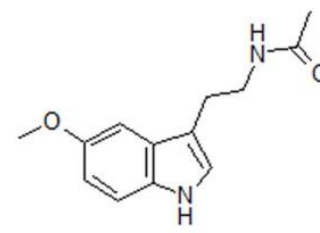

Melatonin (Mel)

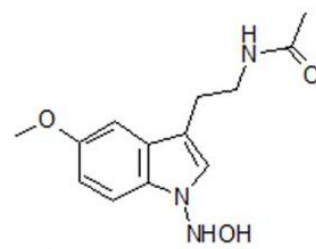

1-Hydroxylaminomelaton in (1-OHAm-Mel)

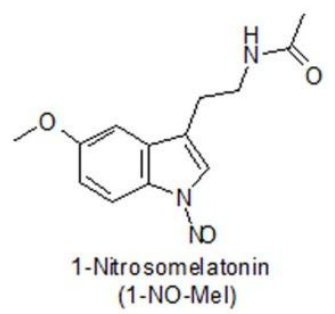

(1-NO-Mel)<smiles>COc1ccc(N)c(C(=O)CCNC(C)=O)c1</smiles>

$N^{1}$-Acetyl-5-methoxy kynuramine (AMK)<smiles>COc1cc(C(=O)CCNC(C)=O)c(N)c([N+](=O)[O-])c1</smiles>

$N^{1}$-Acetyl-5-methoxy-3-nitrokynuramine (AMNK = 3-nitro-AMK)<smiles>COc1ccc(NNO)c(C(=O)CCNC(C)=O)c1</smiles>

$N^{1}$ Acetyl- $N^{2}$-hydroxylamin 0-5-methoxykynuramine (A-OHAm-MK)<smiles>COc1ccc2[nH]nc(CNC(C)=O)c(=O)c2c1</smiles>

3-Acetamidomethyl-6-methoxycinnolinone (AMMC)
Figure 1.

Structures of melatonin, its metabolite $N^{1}$-acetyl-5-methoxykynuramine, their hydroxylamino intermediates, nitrosated and nitrated products.
The ensemble of modulatory effects exerted by melatonin and AMK seems to substantially contribute to the avoidance of dysfunctions at mitochondrial and cellular levels, including possible consequences for apoptosis, inflammationrelated necrosis and, presumably, also parthanatos and autophagy. Prevention of NO-dependent $\mathrm{Ca}^{2+}$ overload and NO-promoted mitochondrial dysfunction by the indoleamine and its metabolite should be perceived in its significance for attenuation of free radical generation in more general terms, including the formation of organic, oxygen and carbonate radicals. From a pathophysiological point of view, the importance of radical avoidance [7-9] exceeds by far the solely biochemical aspects of damaged biomolecules to be replaced or repaired. Partial blockades within the mitochondrial electron transport chain (ETC), which lead to electron leakage and, thus, secondarily augmented radical formation, also cause ATP deficiency and, eventually, cytochrome c release that initiates apoptosis [9-15]. Especially in neurons, ETC malfunction can change the mitochondrial fragmentation/fission balance, which ultimately leads to losses of peripheral mitochondria, synaptic function and connectivity [9, 14-16]. Tyrosine nitration, another consequence of enhanced NO formation, is potentiated especially in conjunction with high $\mathrm{CO}_{2} / \mathrm{HCO}_{3}{ }^{-}$levels, which are normally present in mitochondria, but may become relevant in the cytosol or body fluids during hypoxia/hypercapnia because of impaired blood flow and also in ischemia/reperfusion [17]. This type of protein modification can result, among other effects, in dysfunctional reuptake of neurotransmitters that further promotes neuronal overexcitation, or, in the circulation, to modified atherosclerotic plaque proteins which are more resistant to degradation.

These scenarios shed light on the potential value of compounds that allow NO synthases (NOS) to operate at low or moderately enhanced activities, but are, on the other hand, capable of preventing extreme, disadvantageous rises of NO with its deleterious consequences. Melatonin seems to fulfill these requirements.

\section{Damage by reactive nitrogen species}

Reactive nitrogen species (RNS) should not be regarded as just another subtype of free radicals and related compounds, which cause more or less the same damage to important biomolecules as known from reactive oxygen species (ROS). It seems necessary to perceive several peculiarities, namely, (i) the specific molecular differences in protein modification, (ii) the consequences of protein modification by RNS in functional and pathophysiological terms, (iii) redonation of RNS from scavengers, and (iv) the stimulation of ROS formation by RNS. 
The primary RNS is the NO radical $(\cdot \mathrm{NO})$ formed by NO synthases (NOS). Depending on the different regulation mechanisms controling the isoenzymes iNOS (inducible NOS), nNOS (neuronal NOS) and eNOS (endothelial NOS), including mitochondrially located variants, the production of this nitrogen radical is contextual. Other NO congeners do exist, but are of lower physiological and pathophysiological significance. The nitroxyl cation, $\mathrm{NO}^{+}$, can be generated in biological material, e.g., from nitrosothiol groups of $S$-nitrosocysteine (CysNO) or $S$-nitrosoglutathione (GSNO), but also by copper- or iron-containing metalloproteins, in particular, deoxygenated hemoglobin [18]. The $\bullet \mathrm{NO}$ metabolite nitrite is reduced by $\mathrm{Hb}\left(\mathrm{Fe}^{\mathrm{II}}\right)$, leading to the unstable complexes $\mathrm{Hb}\left(\mathrm{Fe}^{\mathrm{III}}\right) \bullet \mathrm{NO}$ and $\mathrm{Hb}\left(\mathrm{Fe}^{\mathrm{II}}\right) \mathrm{NO}^{+}$, which are in equilibrium and release either $\cdot \mathrm{NO}$ or $\mathrm{NO}^{+}$ [19]. The decomposition of $\mathrm{Hb}\left(\mathrm{Fe}^{\mathrm{III}}\right) \cdot \mathrm{NO}$ to $\mathrm{Hb}\left(\mathrm{Fe}^{\mathrm{II}}\right)$ and $\mathrm{NO}^{+}$can be hardly distinguished from the decay of $\mathrm{Hb}\left(\mathrm{Fe}^{\mathrm{II}}\right) \mathrm{NO}^{+}$. $\mathrm{NO}^{+}$is reportedly formed in arterioles, capillaries and venules even when NO synthase is experimentally inhibited and despite the rapid reaction of $\mathrm{NO}^{+}$in water [20]. Because of its favored combination with $\mathrm{OH}^{-}$, the half-life of $\mathrm{NO}^{+}$in aqueous solution at $\mathrm{pH} 7.4$ is in the range of $10^{-10} \mathrm{~s}$ and, thus, extremely short [21, 22]. Therefore, effects of $\mathrm{NO}^{+}$, as described by others (summarized in ref. [18]), seem to be of low physiological importance.

Another potential source of $\mathrm{NO}^{+}$is the manganese-dependent superoxide dismutase (MnSOD), which was found to catalyze the disproportionation of two $\cdot \mathrm{NO}$ to $\mathrm{NO}^{+}$and $\mathrm{NO}^{-}$ [23]. The nitroxyl anion $\mathrm{NO}^{-}$is, however, immediately protonated at physiological $\mathrm{pH}$ to HNO [24, 25]. At first glance, one might assume that this NO congener, being a reduced compound, would not be involved in oxidative and nitrosative processes, but, in fact, $\mathrm{HNO}$ is an efficiently nitrosating agent [18]. However, HNO is obviously not involved in nitration processes [26].

A chemically and pathophysiologically critical step in the various RNS interconversion reactions is the combination of $\cdot \mathrm{NO}$ with the superoxide anion $\left(\cdot \mathrm{O}_{2}{ }^{-}\right)$. Since $\cdot \mathrm{O}_{2}^{-}$has a similar affinity to the free radical $\bullet \mathrm{NO}$ as to the SODs, this reaction is practically unavoidable. The resulting product, peroxynitrite $\left(\mathrm{ONOO}^{-}\right)$, represents a compound of high reactivity. Various interactions with biomolecules have been ascribed to this intermediate, but, in fact, direct reactions of peroxynitrite with organic metabolites - including melatonin - can be hardly distinguished from others by peroxynitrite-derived free radicals [14]. The non-radical RNS, peroxynitrite, undergoes, in particular, two combination reactions of high pathophysiological relevance. One of them, protonation of the anion, leads to the unstable peroxynitrous acid $(\mathrm{ONOOH})$, which readily decomposes to a hydroxyl radical $(\bullet \mathrm{OH})$ and nitrogen dioxide $\left(\cdot \mathrm{NO}_{2}\right)$. The other one consists of adduct formation with $\mathrm{CO}_{2}$, an abundantly available compound, especially in mitochondria. The resulting molecule, $\mathrm{ONOOCO}_{2}^{-}$, decomposes correspondingly to a carbonate radical $\left(\cdot \mathrm{CO}_{3}{ }^{-}\right)$and - $\mathrm{NO}_{2}$ [9, 14, 15, 17, 27-29]. The devastating, mutagenic and carcinogenic properties of the extremely reactive hydroxyl radical are well-known [30]. The less reactive carbonate radical is still capable of abstracting electrons or hydrogens from various partner molecules, as observed with $\bullet \mathrm{OH}$, but does not form comparable hydroxylated adducts [8, 17, 27, 29, 31, 32]. Frequently, oxidation reaction rates are strongly enhanced by addition of bicarbonate as a source of $\cdot \mathrm{CO}_{3}^{-}$, which can be generated either via $\mathrm{CO}_{2}$, or from $\mathrm{HCO}_{3}^{-}$by interaction with $\cdot \mathrm{OH}[17,31,32]$. These findings shed light on the damaging potential of $\mathrm{CO}_{3}^{-}$, which has a much longer lifetime and, therefore, a considerably larger radius of action than $\cdot \mathrm{OH}$, partially because of resonance stabilization.

The combination of either $\cdot \mathrm{OH}$ or $\cdot \mathrm{CO}_{3}^{-}$with $\cdot \mathrm{NO}_{2}$, however, gives rise to other, pathophysiologically highly relevant products. Although the classic nitration of aromates is of a non-radical nature, the combinations mentioned represent physiological nitration mixtures based on free radical reactions [17, 28, 29, 31, 32]. Most frequently, tyrosine nitration is observed and measured under pathophysiological conditions. For instance, 3-nitrotyrosine is extensively present in atherosclerotic plaques [33-38]. The roles of LDL tyrosine nitration and the contribution of iNOS of macrophages acting on the plaque areas have been well documented. Moreover, the nitrated proteins are relatively more resistant to proteolytic removal. Meanwhile, tyrosine nitration has been implicated in numerous diseases, in particular, aspects of inflammation including rheumatoid diseases, insults by ischemia/reperfusion, cancer, and various neurodegenerative disorders, such as Alzheimer's disease, Huntington's disease, Parkinson's disease, and amyotrophic lateral sclerosis [39-41].

Numerous biologically important proteins have been identified to be impaired by tyrosine nitration, under various pathological conditions and leading to a plethora of consequences. To mention a few 
examples, tyrosines are site-specifically nitrated in: L-type $\mathrm{Ca}^{2+}$ channel $\mathrm{hCa}_{\mathrm{v}} 1.2 \mathrm{~b}$ [42]; microvascular protein phosphatase $2 \mathrm{~A}$, an effect that prevents inactivation by phosphorylation and leads to endothelial barrier dysfunction [43]; $\alpha$ subunit of arterial voltage-gated potassium channel $\mathrm{K}_{\mathrm{v}} 1.2$, especially observed in diabetic rats [44]; $\alpha, \beta$ and FXYD subunits of renal Na-K-ATPase, related to renal dysfunction [45]; glyceraldehyde 3-phosphate dehydrogenase, peripheral-type benzodiazepine receptor, MAP kinase Erk-1, and glutamine synthetase in astrocytes [46], and, perhaps, the synaptosomal glutamate transporter [47], presumably effects with consequences for extracellular glutamate concentrations; midbrain dopamine transporter and vesicular monoamine transporter-2 [48], modifications relevant to Parkinson's disease; $\alpha$ subunit of I $\kappa$ B, which leads to activation of the transcription factor NF-kB [49].

Proteomics and detailed analyses revealed that tyrosine nitration has a particular impact in mitochondria. After ischemia/reperfusion, 23 cardiac proteins were identified to be specifically tyrosine-nitrated, among which 10 were mitochondrially located [50]. In this and other studies, several subunits of complexes I and III as well as the ATP synthase $\alpha$ subunit were affected $[50,51]$. In other systems, the complex I subunit NDUFB8 [52], the Fp subunit of complex II [52, 53], mitochondrial creatine kinase, dihydrolipoamide dehydrogenase, and the voltagedependent anion channel VDAC1 [52] were reported to be tyrosine-nitrated.

The mitochondrial effects of RNS by far exceed these nitrative protein modifications. On the one hand, the peroxynitrite-derived radicals $\cdot \mathrm{OH}$ and - $\mathrm{CO}_{3}{ }^{-}$are also capable of causing oxidative damage to proteins and lipids [9, 14-16]. Oxidative modification of ETC proteins likewise impairs the mitochondrial electron flux. Moreover, peroxidation of cardiolipin plays an additional, significant role in ETC dysfunction, as this specific lipid is required for the structural integrity of complexes III and IV [9, 14, 15, 54-57]. Additionally, $\cdot \mathrm{NO}$ multiply interacts with components of the ETC. As a ligand of transitions metals, it can bind to protein-bound iron present in iron-sulfur clusters and to heme/hemin iron of cytochromes $[9,14]$. $\bullet \mathrm{NO}$ and its nitrosating derivatives can form $S$-nitrosothiols in respirasomal proteins. When synthesized at elevated levels leading to high peroxynitrite concentrations, the combination of $\bullet \mathrm{NO}$ and $\cdot \mathrm{NO}_{2}$ causes the formation of $\mathrm{N}_{2} \mathrm{O}_{3}$, a strongly nitrosating agent $[9,16]$.
Complex I of the ETC is particularly vulnerable to $S$-nitrosation [58]. Moreover, soluble $S$-nitrosothiols, such as $S$-nitrosocysteine or $S$-nitrosoglutathione formed under the influence of nitrosating RNS, are known to transnitrosate protein thiols in ETC complexes [9, 14, 15, 58, 59].

In summary, all these effects by RNS and their derivatives described, i.e., binding of $\cdot \mathrm{NO}$ to ETC irons, $S$-nitrosation, nitration and oxidation of respirasomal proteins, as well as peroxidation of lipids in the inner mitochondrial membrane, in particular, cardiolipin, can cause ETC dysfunction, since they block electron flux to a variable degree depending on the rates of $\bullet \mathrm{NO}$ formation. Moderately elevated concentrations of $\bullet \mathrm{NO}$ are not per se detrimental, but have, on the contrary, even been judged to be beneficial because of $\cdot \mathrm{OH}$ scavenging, initiation of cGMP-mediated processes and stimulation of mitochondrial biogenesis $[9,60-$ 66]. However, secondary bottlenecks or regional blockades of the ETC cause interruption of electron flux, eventually electron backflow and electron leakage [9, 14-16]. Anyway, the interactions of respirasomes and their mediating redox partners do not allow a steady, continual flux of electrons, as became apparent by the discovery of superoxide flashes [67, 68]. The highly dynamic system of electron flux even allows transient openings of the mitochondrial permeability transition pore (mtPTP) without causing immediate breakdown of the mitochondrial membrane potential $\left(\Delta \Psi_{\mathrm{m}}\right)$ and apoptosis induction $[68,69]$, contrary to the former belief. However, persistent partial blockades of electron flux, as caused by an excess of nitrosating, nitrating and oxidizing RNS, represent a key feature of mitochondrial dysfunction. Electron leakage has especially been studied at complexes I and III. Previously, this had been mainly related to changes between respiration states, such as state 3 or 4 respiration. Although this is certainly of relevance, actual considerations should rather be more directed towards the appearance of bottlenecks within the ETC $[9,14,15]$.

The sites at which $\cdot \mathrm{O}_{2}^{-}$is generated by electron transfer to $\mathrm{O}_{2}$ have been recently summarized [9, 14, 15]. Electrons dissipate from complex I mainly via the iron-sulfur cluster $\mathrm{N} 2$ of the amphipathic ramp, an extrusion of this respirasome to the matrix. Therefore, $\cdot \mathrm{O}_{2}^{-}$formed at this site directly enters the matrix. Electron leakage from complex III occurs especially at the Qo site, upon interruption of intramonomer electron transfer between the two $b_{\mathrm{L}}$ hemes. In this case, $\cdot \mathrm{O}_{2}^{-}$is released to both sides of the inner mitochondrial 
membrane. Superoxide formation from complex IV has been rarely investigated directly, but the recently reported identity of the NADPH oxidase subform Nox 4 with a subunit within this complex [83] would indicate a significant contribution of this respirasome to radical formation.

Transitory interruptions of electron flux, as caused by RNS and peroxynitrite-derived oxidizing radicals, lead to electron leakage. As soon as elevated levels of $\bullet \mathrm{NO}$ and peroxynitrite are generated, rates of $\cdot \mathrm{O}_{2}^{-}$formation increase considerably, with the unavoidable consequence of a further rise in peroxynitrite, as long as sufficient amounts of $\bullet \mathrm{NO}$ are present. The remarkable, selfstimulatory relationship between RNS-mediated ETC blockades and ROS formation implies that nitrosative/nitrative stress additionally becomes a cause of oxidative stress. The - in cybernetic terms - positive feedback loop from the $\mathrm{ROS} \cdot \mathrm{O}_{2}{ }^{-}$to the RNS peroxynitrite may end up in a vicious cycle leading to apoptosis or other forms of cell death. While $\cdot \mathrm{O}_{2}^{-}$can be enzymatically partially detoxified by SODs, though in competition with -NO, no enzymatic mechanisms exist for the elimination of $\bullet \mathrm{NO}, \cdot \mathrm{NO}_{2}, \mathrm{~N}_{2} \mathrm{O}_{3}, \cdot \mathrm{OH}$ and $\bullet \mathrm{CO}_{3}^{-}$, so that the ongoing process cannot be easily halted. This can be particularly dramatic under inflammatory conditions, especially in sepsis [10$12,71-73]$, in which $\cdot \mathrm{NO}$ and its reactive metabolites are, in the extreme, capable of totally blocking respiration $[15,73]$. Under such conditions, the relevance of the mitochondrial RNS/ROS loop has been impressively demonstrated by the relative maintenance of mitochondrial electron flux and ATP synthesis in iNOS double knockout mice $[10,12,71,74]$.

It is a remarkable fact that melatonin is one of the few compounds that display the potential of efficiently antagonizing mitochondrial dysfunction, as initiated and maintained by elevated $\bullet \mathrm{NO}$ synthesis, production of peroxynitrite and dramatically increasing electron leakage.

\section{Direct interactions with reactive nitrogen species}

Direct chemical interactions of melatonin with RNS do exist. Whether or not this is physiologically relevant with regard to melatonin concentrations may be questioned, but could become of interest in experiments using pharmacological doses. Nitrosation of melatonin has been observed under various conditions, but nitration was usually not observed, even not in the presence of peroxynitrite and hydrogen carbonate
[75-77]. Instead, peroxynitrite gave rise to nitrosation and oxidation products. The preferential site of nitrosation is the indolic nitrogen of melatonin, to give 1-nitrosomelatonin $(=\mathrm{N}$ nitrosomelatonin; Fig.1). The - to a certain degree surprising - nitrosation of melatonin by peroxynitrite, which contrasts with the nitration reactions observed with other aromates, was explained in different ways (Fig.2). The peroxynitrite-derived free radicals $\cdot \mathrm{NO}_{2}$ or $\cdot \mathrm{CO}_{3}{ }^{-}$ are capable of abstracting a hydrogen from melatonin, thereby forming a melatonyl radical. Additionally, an electron may be abstracted from peroxynitrite, e.g., by $\bullet \mathrm{NO}_{2}$, to give a nitrosodioxyl radical $(\bullet \mathrm{ONOO}$; the radical analog of peroxynitrite) and $\mathrm{NO}_{2}^{-}$. At C-atom 3, the melatonyl radical might undergo an intermediate addition reaction with the nitrosodioxyl radical, followed by its decomposition into $\cdot \mathrm{NO}$ that is attached to ring atom 1 and $\mathrm{O}_{2}$ which is released [77]. Alternately, a reaction of melatonin with the nitrosodioxyl radical, formed from $\bullet \mathrm{NO}$ and $\mathrm{O}_{2}$, was discussed [77]. The nitrosodioxyl radical might directly attach to $\mathrm{C} 3$ of melatonin, thereby forming the indolic radical adduct, followed by decomposition to $\cdot \mathrm{NO}$, which interacts with ring atom 1, under release of a hydroperoxyl radical $\left(\cdot \mathrm{HO}_{2}\right)$ (Fig.2). Although these reactions are chemically possible, it should be kept in mind that, in systems generating both $\bullet \mathrm{NO}$ and $\bullet \mathrm{NO}_{2}$, the formation of the strongly nitrosating $\mathrm{N}_{2} \mathrm{O}_{3}$ is also possible (Fig. 2), and also the sequential hydrogen abstraction by $\cdot \mathrm{NO}_{2}$ and addition of $\cdot \mathrm{NO}$. In fact, melatonin nitrosation was observed using the combination of $\bullet \mathrm{NO}_{2}$ and $\bullet \mathrm{NO}$ [78].

Nitroxyl (HNO, the protonated $\mathrm{NO}^{-}$congener) was identified as another agent capable of nitrosating melatonin at the pyrrole nitrogen [79]. In this case, HNO should be directly attached to the nitrogen, to give a melatonin $N$-hydroxylamine (= 1-hydroxylaminomelatonin, 1-OHAm-Mel; Fig.1), which may either transfer two hydrogens to $\mathrm{O}_{2}$, to give $\mathrm{H}_{2} \mathrm{O}_{2}$ and 1-nitrosomelatonin, or decompose into a melatonyl radical and $\cdot \mathrm{HNOH}$, which, upon transfer of 2 hydrogens to $\mathrm{O}_{2}$, would form $\cdot \mathrm{NO}$ that combines with the melatonyl radical (Fig.2).

All these reactions leading to the nitrosation of melatonin should not be misinterpreted in terms of scavenging, since 1-nitrosomelatonin readily redonates $\cdot \mathrm{NO}$ [80-82]. Although one might argue that a more dangerous compound, peroxynitrite, is exchanged in the respective nitrosation and redonation reactions by the less reactive $\cdot \mathrm{NO}$, the reformation of peroxynitrite is still possible, so that, 
in terms of protection, the balance may be poor. On the other hand, the use of 1-nitrosomelatonin as a pharmacologically suitable $\bullet \mathrm{NO}$ donor was proposed, which might combine the property of releasing this gaseous regulator molecule with the protective potential of melatonin related to its antioxidant, antiinflammatory and antiexcitatory actions [81].

Direct interactions with RNS can be observed also with some melatonin metabolites. The indolic analogs are less of interest, compared to the kynuramine metabolite AMK. This compound

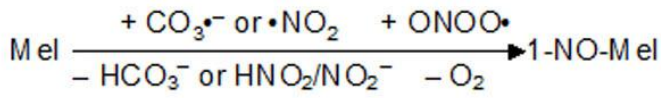

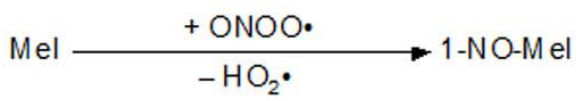

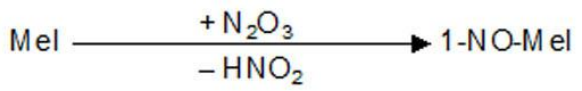

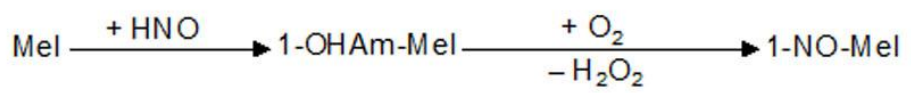
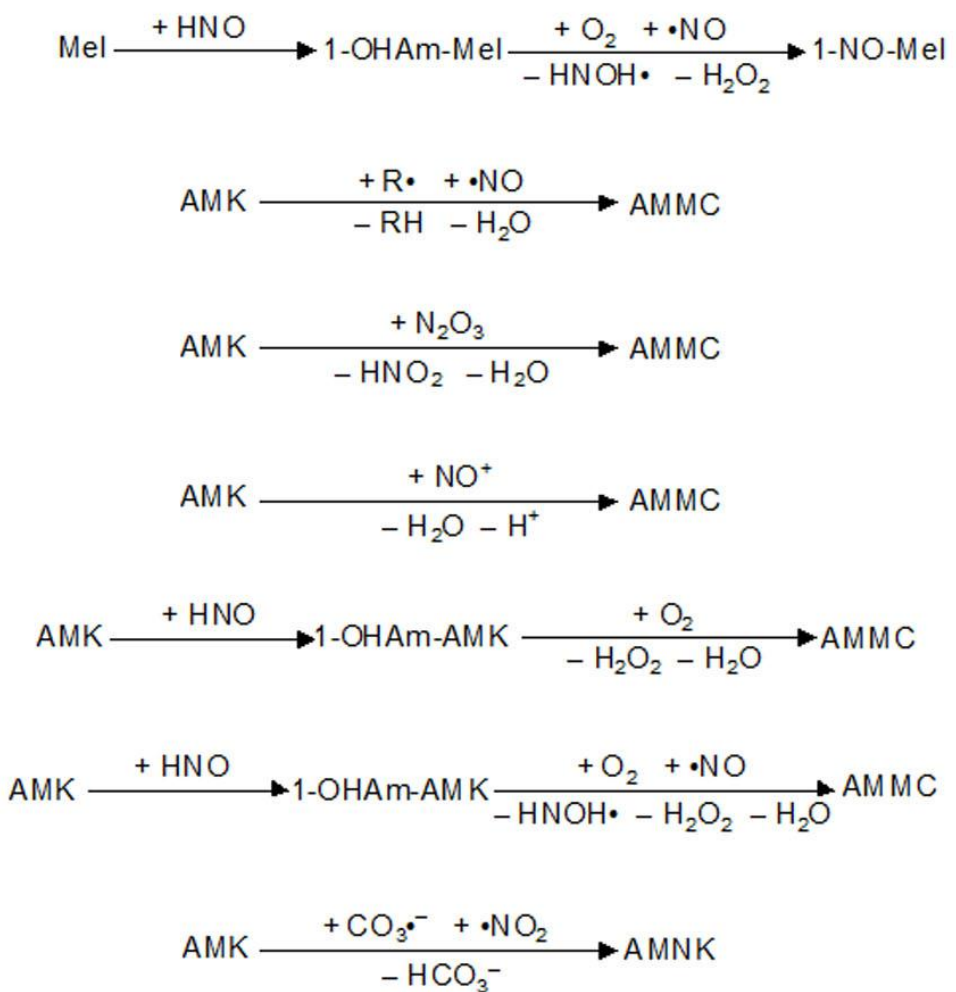

displays a much higher reactivity than its precursor $N^{1}$-acetyl- $N^{2}$-formyl-5-methoxykynuramine (AFMK) $[6,8,83,84]$. This difference was also obvious with nitrosating and nitrating agents [18]. By contrast with melatonin, AMK is nitrated to $N^{1}$-acetyl-3-nitro-5-methoxykynuramine (= 3-nitro$\mathrm{AMK}=\mathrm{AMNK}$; Fig.1) in reaction mixtures forming the peroxynitrite- $\mathrm{CO}_{2}$ adduct and, thus, $\cdot \mathrm{CO}_{3}{ }^{-}$and $\cdot \mathrm{NO}_{2}$ [29]. In the absence of $\mathrm{CO}_{2} / \mathrm{HCO}_{3}{ }^{-}$ , AMK was preferentially oxidized [29], reflecting is properties of a potent $\cdot \mathrm{OH}$ scavenger $[83,84]$.
Figure 2.

The various nitrosation and nitration reactions of melatonin and $N^{1}$-acetyl-5-methoxykynuramine (AMK). $\mathrm{R} \cdot$ : hydrogen-abstracting radical; other abbreviations as in Fig.1. For further details see current text. 
Another difference to melatonin concerns the formation of a stable nitrosation product $[18,29$, 85]. This compound was identified as 3-acetamidomethyl-6-methoxycinnolinone (AMMC; Fig.1) [29]. Contrary to 1-nitrosomelatonin, this metabolite does not easily re-donate $\cdot \mathrm{NO}$, because of the nitrogen incorporation into a second, resonance-stabilized ring [6, 85]. Moreover, AMK did not form, upon nitrosation, azo-adducts, toxic diazonium or carbenium anions [6, 85] nor oxadiazoles or o-quinone diazides [6] known from other aromates including some kynuric compounds [86]. AMMC is formed from AMK by interaction with all three NO congeners, which are efficiently scavenged by the methoxylated kynuramine [18]. The mechanisms are similar to those mentioned for melatonin, but have to include water release in the cyclization reaction (Fig.2). Nitrosation by $\mathrm{NO}^{+}$ only requires deprotonation and water release. The corresponding reaction with $\bullet \mathrm{NO}$ additionally requires hydrogen abstraction, which is, however, easily possible in systems containing reactive nitrogen species and in biological material as well. Hydrogen abstraction by $\cdot \mathrm{NO}_{2}$ followed by interaction with $\bullet \mathrm{NO}$ is possible as much as nitrosation by $\mathrm{N}_{2} \mathrm{O}_{3}$, the $\cdot \mathrm{NO} / \cdot \mathrm{NO}_{2}$ adduct [6]. Nitrosation by $\mathrm{HNO}$ should proceed via the respective $N$-hydroxylamine, followed by one of the two reaction pathways mentioned for 1nitrosomelatonin formation $\left(2 \mathrm{H}\right.$ transfer to $\mathrm{O}_{2}$; alternately, formation of AMKyl radical and - $\mathrm{HNOH}$, which generates $\cdot \mathrm{NO}$ that combines with the AMKyl radical) [18]. Again, the $N^{2}$-nitrosoAMK cyclizes under release of water.

As discussed for melatonin, the relevance of these reactions may largely be restricted to pharmacological concentrations, upon administration of AMK or its precursor, melatonin. Under experimental conditions, an additional type of reaction observed with AMK may interfere with RNS metabolism. Under oxidative conditions leading to $N^{2}$-centered radicals, AMK forms adducts with aromates, in particular, tyrosine [87]. Protein AMKylation may prevent not only phosphorylation or chlorination of tyrosine residues, but also 3-nitrotyrosine formation. However, this remains to be studied in quantitative terms.

\section{Regulation of NO synthases by melatonin and AMK}

The control of NOS subforms by melatonin and AMK is of particular relevance, especially as lower concentrations of these compounds are required.
Moreover, the consequences of limiting the formation of $\bullet \mathrm{NO}$ and peroxynitrite seem to be more profound and of premier importance under many aspects of protection.

The three NOS isoenzymes are not only differently regulated by other stimuli, but also differently affected by melatonin. Effects of melatonin on eNOS, which is expressed in endothelial cells and some other cell types, have not been extensively studied under otherwise noncompromised conditions. Therefore, findings concerning a melatonin-mediated prevention of eNOS induction by $\mathrm{H}_{2} \mathrm{O}_{2}$ [88], may be rather interpreted in terms counteraction against oxidative stress and may not allow conclusions on direct eNOS regulation by melatonin. Moreover, observations made in different systems including ischemia/reperfusion of various organs did not reveal consistent effects concerning up- or downregulation of eNOS and, similarly, the actions of melatonin on this isoenzyme were either stimulatory $[89,90]$, preventive against decreases [91], or negligible [92]. Contradictory findings on eNOS regulation by melatonin are not that much surprising, since the indoleamine displays regionally different effects in the vascular system, depending on the expression of melatonin receptor subtypes. Actions via $\mathrm{MT}_{1}$ cause vasoconstriction by opening of $\mathrm{BK}_{\mathrm{Ca}}$ channels, whereas those via $\mathrm{MT}_{2}$ result in vasodilation [1, 2, 93-96]. Therefore, downregulation of eNOS during $\mathrm{MT}_{2}$-mediated dilation responses would be functionally counterproductive and, if at all, the opposite should be expected.

Much more is known about the regulation of iNOS and nNOS by melatonin. iNOS is expressed in numerous tissues and cells. It is of utmost importance under inflammatory conditions, under which this isoenzyme is strongly upregulated by pro-inflammatory leukocytes, in particular, neutrophils and macrophages [97-99]. This is the more important as, in the same situation, proinflammatory cytokines and other mediators such as prostaglandins are also induced, which further stimulate iNOS-related processes and, additionally, NOX subforms that generate considerable amounts of $\cdot \mathrm{O}_{2}^{-}$, so that the formation of peroxynitrite is promoted from two sides. It should be noted that melatonin as well as its metabolites AFMK and AMK downregulate COX-2, at least, at pharmacological concentrations [100], and that AMK is a COX inhibitor more potent than aspirin [101], perhaps, with some COX-2 specificity [96]. Anti-nitrative and anti-nitrosative actions can, thus, 
be assumed for melatonin, AFMK and AMK because of their antiinflammatory actions. Direct effects of melatonin on NOX expression have not been studied in detail, although the oxidative stress induced by upregulation can be blunted by the indoleamine.

The induction of iNOS by inflammatory signals can be efficiently prevented by melatonin, what has been convincingly demonstrated in models of bacterial lipopolysaccharide exposure [102, 103] and sepsis caused by cecal ligation and puncture [10-12, 71, 74, 104], effects that were consistently obtained in various organs such as diaphragm, heart, lung and liver. As will be discussed in the next section, this action of melatonin strongly attenuated mitochondrial damage. The relevance of iNOS suppression was supported by similar findings on prevention of mitochondrial dysfunction in homozygous iNOS knockouts [10, 12, 71, 74]. Moreover, the presence of a mitochondrial iNOS variant was shown, which may be of particular relevance in ETC dysfunction, which is also absent in the knockouts and whose upregulation is likewise prevented by melatonin [10-12, 71, 103, 105]. Suppression of both cytosolic and mitochondrial iNOS variants was also obtained in a model of parkinsonism using MPTP (1-methyl4-phenyl-1,2,3,6-tetrahydropyridine), a neurotoxin specific for dopaminergic neurons with particular mitochondrial toxicity [106]. Interestingly, this effect was not only obtained with melatonin, but also with AMK [106].

Negative regulation by melatonin was also shown in the case of nNOS, which is directly inhibited by the indoleamine [107-110]. Again, AMK displayed a similar action $[109,110]$ and, despite a higher $\mathrm{K}_{\mathrm{i}}$ value, inhibitions by the kynuramine were demonstrable down to $10^{-11} \mathrm{M}$ [110]. Generally, members of the kynurenine family were found to be more potent nNOS inhibitors than melatonin, provided that they are not substituted at $N^{2}$ [107]. The contributions of AMK to the effects of melatonin are, however, uncertain as long as concentration measurements of the kynuric metabolite have not been provided. It may be difficult to obtain reliable data because of the transitory nature of AMK, which undergoes numerous reactions with ROS, RNS and other molecules [6].

The practical value of melatonin and, perhaps, AMK should be seen in the prevention of damage caused by excessive $\cdot \mathrm{NO}$ production, especially in conjunction with high rates of $\cdot \mathrm{O}_{2}^{-}$formation, which lead to undesirable peroxynitrite levels. This would especially be the case under conditions of inflammation and in several neurodegenerative disorders. Although peroxynitrite and its products are responsible for a variety of diseases, basal or moderately enhanced $\bullet \mathrm{NO}$ levels are obviously not detrimental, but rather beneficial [9, 60-66, 111]. Therefore, the intention should never be to totally suppress •NO formation, nor should the physiological role of melatonin be sought in a complete downregulation of melatonin-sensitive NOS subforms. This becomes particularly evident in the circadian rhythmicity of central nervous $\bullet \mathrm{NO}$ production in nocturnal animals. In these species, the amount of $\bullet \mathrm{NO}$ generated should largely reflect neuronal activity, and its maximum should be expected to coincide with the nocturnal melatonin peak [7]. In fact, this was observed in rats, and even aged animals which can be assumed to produce less melatonin did not show dramatic differences in the -NO rhythm, compared to young animals [112]. Nocturnal -NO maxima were also described in other organs of nocturnal rodents [7, 113].

Nevertheless, melatonin should be regarded as potentially highly valuable pharmacological tool in treating diseases related to damage by peroxynitrite.

\section{Significance to mitochondria - role in radical avoidance}

In conjunction with the downregulation of melatonin-sensitive NOS subforms (Fig.3), protection and improvements of ETC function were repeatedly observed. Melatonin was shown to prevent, in sepsis models, $\cdot \mathrm{NO} /$ peroxynitritedependent decreases in the activities of complexes I and IV, sometimes also complexes II and III of the ETC of various organs [10, 12, 103, 105, 114], and it also protected against multi-organ failure [104]. These effects were accompanied by the maintenance of ATP production and energy efficiency in the compromised animals $[12,74,105$, 114], results that are insofar important, as they indicate the in vivo support of electron flux, whereas the respirasomal activities had been determined in submitochondrial particles. Similar results were also obtained for some of the parameters mentioned with AMK $[105,106]$. Of course, the protection of the ETC comprises an additional antioxidant effect. This conclusion is in accordance with the observed suppression of lipid peroxidation [10,71, 102], maintenance of reduced glutathione levels [71, 114], of glutathione peroxidase and glutathione reductase activities [10, 71]. The effects on these enzymes and also on de novo synthesis of respirasomal subunits may reflect 
direct stimulatory actions of melatonin at the level of gene expression [15] and, in the balance, may be difficult to distinguish from the consequences of NOS downregulation. On the other hand, rises in peroxynitrite would also cause lipid peroxidation, damage to ETC proteins and, therefore, enhanced electron dissipation and oxidant formation, which leads to consumption of reduced glutathione. As outlined in the section on damage by RNS, nitrosative/nitrative and oxidative forms of stress are multiply interconnected and cannot be fully dissected, in a given pathophysiological situation.

Another important aspect concerning the maintenance of mitochondrial function is related to protection against neurodegenerative disorders. In these cases, both nNOS and iNOS can be involved, depending on an inflammatory component, which may be even atypical and lingering. Although these pathologies and beneficial effects of melatonin, as far as they exist, are much more complex than just described by nitrosative/nitrative and oxidative stress and protection thereof, a contribution of RNS and mitochondrial dysfunction to these diseases remains [115-119]. In several experimental studies, damage by the neurotoxin MPTP was shown to be counteracted by melatonin [120], but protection at the mitochondrial level as related to iNOS synthase suppression was not demonstrated before recently [106]. In this investigation, complex I activity was shown to be normalized, in striatum and substantia nigra, by both melatonin and AMK.

The roles of RNS and mitochondrial dysfunction in aging, as well as the value of melatonin in antagonizing these processes have been extensively reviewed in the last years [9, 14-16]. The studies summarized there clearly indicate a beneficial role of melatonin in maintaining electron flux capacity and ATP formation, reducing damage to the ETC,

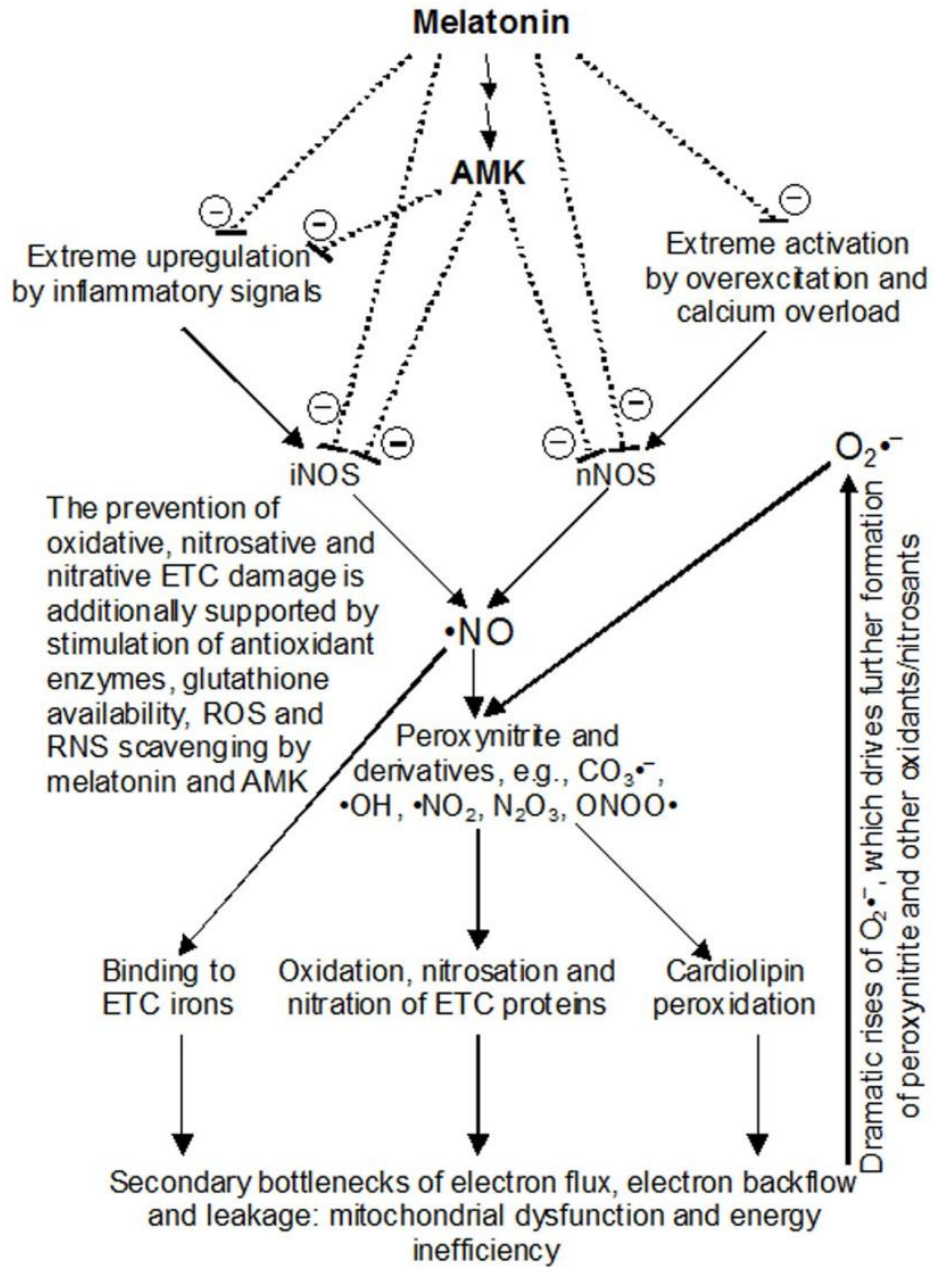

Figure 3.

The vicious cycle of mitochondrial dysfunction started by extreme stimulations of $\bullet \mathrm{NO}$ synthesis, followed by peroxynitrite formation and damage to the ETC, with the consequence of strongly enhanced $\cdot \mathrm{O}_{2}{ }^{-}$generation by electron leakage that drives further peroxynitrite production. Dotted lines: Blunting the vicious cycle by various antiinflammatory and antiexcitatory actions of melatonin and its metabolite AMK and by downregulation/inhibition of iNOS and nNOS. 
attenuating electron leakage and, thus, oxidant formation as well as other actions concerning mitochondrial biogenesis. Many of these effects could be related to the prevention of excessive formation of $\bullet \mathrm{NO}$, damage by peroxynitrite and its derivatives. Various of these studies have dealt with the senescence-accelerated mouse strain SAMP8, in comparison to the normally aging strain SAMR1, which carries the same genetic background. To mention a few potentially important findings, melatonin was shown to reduce losses of complex I activity in aging SAMP8 mice [121] and to substantially stimulate complex I and IV activities in both SAMP8 and SAMR1 old mice much above control levels [122]. To which extent these rises are consequences of eliminating blockades by RNS remains to be studied in their mechanistic details. Improvements of complex I activity and reductions of electron leakage may well be supported by melatonin via additional pathways acting in a concerted way with the limitation of RNS formation. Removal of a bottleneck at complex I can include enhanced de novo synthesis of ETC subunits, generalized mitochondrial biogenesis and a newly discovered high affinity melatonin binding site $\left(K_{d}=150 \mathrm{pM}\right)$ located in the vicinity of the iron-sulfur cluster $\mathrm{N} 2$ in the amphipathic ramp of complex I (unpublished details cited in refs. [2, 9, $14,15])$.

The removal of bottlenecks within the ETC seems to be a crucial requirement for appropriate mitochondrial function, whether exerted by blunting RNS formation and/or by other, additional means. Therefore, mechanisms supporting electron flux along with attenuations of electron leakage may be regarded as essential components within a regulatory network designed for radical avoidance [7-9]. This new concept does not primarily focus on scavenging of radicals already formed, but rather on the control of processes leading to enhanced radical formation. Breaking the self-stimulatory loop of excessive $\cdot \mathrm{NO}$ generation followed by $\cdot \mathrm{O}_{2}{ }^{-}$ formation via electron dissipation and the appearance of deleterious peroxynitrite levels should be an important element in the system of radical avoidance (cf. Fig.3).

\section{Conclusion}

Melatonin and $\bullet \mathrm{NO}$, this is not simply a story of antagonism. In a normal physiological range, moderate elevations of $\bullet \mathrm{NO}$ are poorly affected by the indoleamine and certainly not entirely suppressed. The decisive property of melatonin in antagonizing undesired nitrosation and nitration as well as oxidative damage by peroxynitrite-derived free radicals consists in the limits set to excessive upregulation of iNOS and nNOS, in conjunction with antioxidative actions, e.g., by supporting the availability of reduced glutathione. The importance of these actions should be seen in the prevention of deleterious levels of peroxynitrite. At the mitochondrial level, this includes the possibility of interrupting the vicious cycle of $\bullet \mathrm{NO}$ - and $\cdot \mathrm{O}_{2}^{-}$dependent inhibitions of electron flux, with its consequence of electron leakage and further oxidant formation. Whether direct modulation of electron flux and eventual prevention of electron backflow by controling complex I activity, at or close to ironsulfur cluster $\mathrm{N} 2$, may contribute to the attenuation of electron dissipation will be an intriguing question to be solved in the future. Additional effects of melatonin concerning enhanced expression of ETC subunits and mitochondrial biogenesis can be assumed to also support electron flux capacity and to avoid electron overflow.

Whether or not melatonin may be suitable for avoiding nitrative damage in cardiovascular diseases remains to be studied in detail. Previously, the focus had been on the antioxidant properties of melatonin and role of RNS had been poorly addressed. In experimental systems, protection of aortic smooth muscles from damage by peroxynitrite has been documented [123]. In a mesenteric ischemia/reperfusion system, melatonin reduced nitrosative/nitrative stress in the intestine and lung of rats [124]. However, it is still uncertain to what extent such findings could be generalized. Protective cardiovascular effects, as summarized elsewhere [125, 126], may be also interpreted in different ways. In this context, antiinflammatory actions of melatonin [126], which comprise multiple mechanisms and are not restricted to the modulation of $\bullet \mathrm{NO}$ formation, may be of relatively higher importance than downregulation of iNOS. Moreover, melatonin-induced rises in $\bullet \mathrm{NO}$ production were also observed in some cases [127, 128], which may reflect the regional distribution of $\mathrm{MT}_{2}$ receptors within the vasculature. Melatonin was also reported to promote aortal atherosclerosis, however, in mice fed an atherogenic diet [129]. Therefore, the suitability of melatonin may be conditional in cardiovascular pathologies and caution is due, before this can be judged on a reliable clinical basis.

With regard to the, sometimes widespread, peroxynitrite-induced damage frequently observed in various neurodegenerative diseases $[9,39-41,48$, $59,60,111,118,130,131]$, melatonin may become 
an option of treatment. In these disorders, several factors can contribute to the overproduction of $\bullet \mathrm{NO}$, such as excitotoxic glutamate levels, $\mathrm{Ca}^{2+}$ overload, and lingering processes of atypical inflammation with microglia activation. It seems relatively certain that mitochondrial dysfunction is involved in these pathologies [9, 15, 16, 59, 118]. During normal aging, similar changes may occur, but proceed at much smaller rates. Inflammation and, in the extreme, sepsis provide the clearest examples for the importance of supranormal NOS upregulation, the deleterious potential of RNS, especially peroxynitrite and its products, and the involvement

\section{References}

1. Hardeland R. Melatonin, hormone of darkness and more occurrence, control mechanisms, actions and bioactive metabolites. Cell Mol Life Sci 2008; 65:2001-18.

2. Hardeland R, Poeggeler B. Melatonin beyond its classical functions. Open Physiol J 2008; 1:1-23.

3. Hardeland R, Balzer I, Poeggeler B, Fuhrberg B, Uría H, Behrmann G, Wolf R, Meyer TJ, Reiter RJ. On the primary functions of melatonin in evolution: Mediation of photoperiodic signals in a unicell, photooxidation and scavenging of free radicals. J Pineal Res 1995; 18:104-11.

4. Tan D-X, Hardeland R, Manchester LC, Paredes SD, Korkmaz A, Sainz RM, Mayo JC, Fuentes-Broto L, Reiter RJ. The changing biological roles of melatonin during evolution: from an antioxidant to signals of darkness, sexual selection and fitness. Biol Rev Camb Philos Soc 2010; 85:607-23.

5. Pandi-Perumal SR, Srinivasan V, Maestroni GJM, Cardinali DP, Poeggeler B, Hardeland R. Melatonin Nature's most versatile biological signal? FEBS J 2006; 273:2813-38.

6. Hardeland R, Tan D-X, Reiter RJ. Kynuramines, metabolites of melatonin and other indoles: the resurrection of an almost forgotten class of biogenic amines. J Pineal Res 2009; 47:109-26.

7. Hardeland R, Coto-Montes A, Poeggeler B. Circadian rhythms, oxidative stress and antioxidative defense mechanisms. Chronobiol Int 2003; 20:921-62.

8. Hardeland R. Antioxidative protection by melatonin Multiplicity of mechanisms from radical detoxification to radical avoidance. Endocrine 2005; 27:119-30.

9. Hardeland R. Neuroprotection by radical avoidance: search for suitable agents. Molecules 2009; 14:5054-102.

10. Escames G, López LC, Tapias V, Utrilla P, Reiter RJ, Hitos $\mathrm{AB}$, León $\mathrm{J}$, Rodríguez MI, Acuña-Castroviejo D. Melatonin counteracts inducible mitochondrial nitric oxide synthase-dependent mitochondrial dysfunction in skeletal muscle of septic mice. J Pineal Res 2006; 40:71-8.

11. Escames G, Acuña-Castroviejo D, López LC, Tan D-X, Maldonado MD, Sánchez-Hidalgo M, León J, Reiter RJ. Pharmacological utility of melatonin in the treatment of septic shock: experimental and clinical evidence. J Pharm Pharmacol 2006; 58:1153-65.

12. Escames G, López LC, Ortiz F, López A, García JA, Ros E, Acuña-Castroviejo D. Attenuation of cardiac mitochondrial dysfunction by melatonin in septic mice. FEBS J 2007; 274:2135-47. of mitochondria in nitrosative/nitrative stress, but also for the powerful counteractions by melatonin, which is capable of blunting these dangerous processes.

The respective actions of melatonin should be seen as a part of the orchestrating functions of this pleiotropic regulator molecule, which contributes at various levels to radical avoidance, from the temporal coordination of antioxidant mechanisms with prevalent phases of oxidant formation, to the antagonism of neuronal overexcitation, control of iNOS and nNOS, and direct as well as indirect mitochondrial modulation [7-9, 14-16].

13. Korkmaz A, Reiter RJ, Topal T, Manchester LC, Oter S, Tan D-X. Melatonin: an established antioxidant worthy of use in clinical trials. Mol Med 2009; 15:43-50.

14. Hardeland R. Melatonin, mitochondrial electron flux and leakage: recent findings and resolution of contradictory results. Adv Stud Biol 2009; 1:207-30.

15. Hardeland R, Poeggeler B, Pappolla M.A. Mitochondrial actions of melatonin - an endeavor to identify their adaptive and cytoprotective mechanisms. Abh Sächs Akad Wiss Math-Nat Kl 2009; 65(Pt 3):14-31.

16. Hardeland R, Coto-Montes A. New vistas on oxidative damage and aging. Open Biol J 2010; 3:39-52.

17. Hardeland $R$, Poeggeler $B$, Niebergall $R$, Zelosko V. Oxidation of melatonin by carbonate radicals and chemiluminescence emitted during pyrrole ring cleavage. $\mathrm{J}$ Pineal Res 2003; 34:17-25.

18. Hardeland $\mathrm{R}$, Backhaus $\mathrm{C}$, Fadavi $\mathrm{A}$. Reactions of the NO redox forms $\mathrm{NO}^{+}, \cdot \mathrm{NO}$ and $\mathrm{HNO}$ (protonated $\mathrm{NO}^{-}$) with the melatonin metabolite $N^{1}$-acetyl-5-methoxykynuramine. J Pineal Res 2007; 43:382-8.

19. Nagababu E, Ramasamy S, Abernethy DR, Rifkind JM. Active nitric oxide produced in the red cell under hypoxic conditions by deoxyhemoglobin-mediated nitrite reduction. J Biol Chem 2003; 278:46349-56.

20. Kashiwagi S, Kajimura M, Yoshimura Y, Suematsu M. Nonendothelial source of nitric oxide in arterioles but not in venules: alternative source revealed in vivo by diaminofluorescein microfluorography. Circ Res 2002; 91:e55-64.

21. Butler AR, Flitney FW, Williams DLH. NO, nitrosonium ions, nitroxide ions and iron-nitrosyls in biology: a chemist's perspective. Trends Pharmacol Sci 1995; 16:1822.

22. Khan S, Kayahara M, Joashi U, Mazarakis ND, Saraf C, Edwards AD, Hughes MN, Mehmet H. Differential induction of apoptosis in Swiss 3T3 cells by nitric oxide and the nitrosonium cation. J Cell Sci 1997; 110:2315-22.

23. Filipović MR, Stanić D, Raičević S, Spasić M, Niketić V. Consequences of MnSOD interactions with nitric oxide: nitric oxide dismutation and the generation of peroxynitrite and hydrogen peroxide. Free Radic Res 2007; 41:62-72.

24. Shafirovich V, Lymar SV. Nitroxyl and its anion in aqueous solutions: spin states, protic equilibria, and reactivities toward oxygen and nitric oxide. Proc Natl Acad Sci USA 2002; 99:7340-5.

25. Bartberger MD, Liu W, Ford E, Miranda KM, Switzer C, Fukuto JM, Farmer PJ, Wink DA, Houk KN. The reduction 
potential of nitric oxide (NO) and its importance to $\mathrm{NO}$ biochemistry. Proc Natl Acad Sci USA 2002; 99:10958-63.

26. Suzuki T, Mower HF, Friesen MD, Gilibert I, Sawa T, Ohshima H. Nitration and nitrosation of $N$-acetyl- $L$ tryptophan and tryptophan residues in proteins by various reactive nitrogen species. Free Radic Biol Med 2004; 37:671-81.

27. Squadrito GL, Pryor WA. Oxidative chemistry of nitric oxide: the roles of superoxide, peroxynitrite, and carbon dioxide. Free Radic Biol Med 1998; 25:392-403.

28. Ducrocq C, Blanchard B, Pignatelli B, Ohshima H. Peroxynitrite, an endogenous oxidizing and nitrating agent. Cell Mol Life Sci 1999; 55:1068-77.

29. Guenther AL, Schmidt SI, Laatsch H, Fotso S, Ness H, Ressmeyer A-R, Poeggeler B, Hardeland R. Reactions of the melatonin metabolite AMK ( $N^{1}$-acetyl-5methoxykynuramine) with reactive nitrogen species: Formation of novel compounds, 3-acetamidomethyl-6methoxycinnolinone and 3-nitro-AMK. J Pineal Res 2005; 39:251-60.

30. Halliwell BB, Gutteridge JMC. Free radicals in biology and medicine. $4^{\text {th }}$ edition. Oxford University Press, Oxford, 2007.

31. Zhang H, Joseph J, Felix C, Kalyanaraman B. Bicarbonate enhances the hydroxylation, nitration, and peroxidation reactions catalyzed by copper, zinc superoxide dismutase. Intermediacy of carbonate anion radical. J Biol Chem 2000; 275:14038-45.

32. Kalyanaraman B, Joseph J, Zhang H. Bicarbonate enhances nitration and oxidation reactions in biological systems-role of reactive oxygen and nitrogen species. Adv Exp Med Biol 2001; 500:175-82.

33. Beckmann JS, Ye YZ, Anderson PG, Chen J, Accavitti MA, Tarpey MM, White CR. Extensive nitration of protein tyrosines in human atherosclerosis detected by immunohistochemistry. Biol Chem Hoppe Seyler 1994; 375:81-8

34. Depre C, Havaux X, Renkin J, Vanoverschelde JL, Wijns W. Expression of inducible nitric oxide synthase in human coronary atherosclerotic plaque. Cardiovasc Res 1999; 41:465-72.

35. Mohiuddin I, Chai H, Lin PH, Lumsden AB, Yao Q, Chen C. Nitrotyrosine and chlorotyrosine: clinical significance and biological functions in the vascular system. J Surg Res 2006; 133:143-9.

36. Kamat JP. Peroxynitrite: a potent oxidizing and nitrating agent. Indian J Exp Biol 2006; 44:436-47.

37. Hamilton RT, Asatryan L, Nilsen JT, Isas JM, Gallaher TK, Sawamura T, Hsiai TK. LDL protein nitration: implication for LDL protein unfolding. Arch Biochem Biophys 2008; 479:1-14.

38. Ponnuswamy P, Ostermeier E, Schröttle A, Chen J, Huang PL, Ertl G, Nieswandt B, Kuhlencordt PJ. Oxidative stress and compartment of gene expression determine proatherosclerotic effects of inducible nitric oxide synthase. Am J Pathol 2009; 174:2400-10.

39. Sultana R, Butterfield DA. Slot-blot analysis of 3nitrotyrosine-modified brain proteins. Methods Enzymol 2008; 440:309-16.

40. Basso M, Samengo G, Nardo G, Massignan $T$, D'Alessandro G, Tartari S, Cantoni L, Marino M, Cheroni C, De Biasi S, Giordana MT, Strong MJ, Estevez AG, Salmona M, Bendotti C, Bonetto V. Characterization of detergent-insoluble proteins in ALS indicates a causal link between nitrative stress and aggregation in pathogenesis. PLoS One 2009; 4:e8130.
41. Nardo G, Pozzi S, Mantovani S, Garbelli S, Marinou K, Basso M, Mora G, Bendotti C, Bonetto V. Nitroproteomics of peripheral blood mononuclear cells from patients and a rat model of ALS. Antioxid Redox Signal 2009; 11:155967.

42. Kang M, Akbarali HI. Denitration of L-type calcium channel. FEBS Lett 2008; 582:3033-6.

43. Wu F, Wilson JX. Peroxynitrite-dependent activation of protein phosphatase type $2 \mathrm{~A}$ mediates microvascular endothelial barrier dysfunction. Cardiovasc Res 2009; 81:38-45.

44. Bubolz AH, Wu Q, Larsen BT, Gutterman DD, Liu Y. Ebselen reduces nitration and restores voltage-gated potassium channel function in small coronary arteries of diabetic rats. Am J Physiol Heart Circ Physiol 2007; 293:H2231-7.

45. Reifenberger MS, Arnett KL, Gatto C, Milanick MA. The reactive nitrogen species peroxynitrite is a potent inhibitor of renal Na-K-ATPase activity. Am J Physiol Renal Physiol 2008; 295:F1191-8.

46. Schliess F, Görg B, Fischer R, Desjardins P, Bidmon HJ, Herrmann A, Butterworth RF, Zilles K, Häussinger D. Ammonia induces MK-801-sensitive nitration and phosphorylation of protein tyrosine residues in rat astrocytes. FASEB J 2002; 16:739-41.

47. Olivenza R, Moro MA, Lizasoain I, Lorenzo P, Fernández AP, Rodrigo J, Boscá L, Leza JC. Chronic stress induces the expression of inducible nitric oxide synthase in rat brain cortex. J Neurochem 2000; 74:785-91.

48. Kanaan NM, Kordower JH, Collier TJ. Age-related changes in dopamine transporters and accumulation of 3nitrotyrosine in rhesus monkey midbrain dopamine neurons: relevance in selective neuronal vulnerability to degeneration. Eur J Neurosci 2008; 27:3205-15.

49. Yakovlev VA, Barani IJ, Rabender CS, Black SM, Leach JK, Graves PR, Kellogg GE, Mikkelsen RB. Tyrosine nitration of I $\mathrm{B} \alpha$ : a novel mechanism for NF- $\mathrm{kB}$ activation. Biochemistry 2007; 46:11671-83.

50. Liu B, Tewari AK, Zhang L, Green-Church KB, Zweier JL, Chen YR, He G. Proteomic analysis of protein tyrosine nitration after ischemia reperfusion injury: mitochondria as the major target. Biochim Biophys Acta 2009; 1794:47685.

51. Lee HM, Reed J, Greeley GH Jr, Englander EW. Impaired mitochondrial respiration and protein nitration in the rat hippocampus after acute inhalation of combustion smoke. Toxicol Appl Pharmacol 2009; 235:208-15.

52. Davis CW, Hawkins $B J$, Ramasamy $S$, Irrinki KM, Cameron BA, Islam K, Daswani VP, Doonan PJ, Manevich Y, Madesh M. Nitration of the mitochondrial complex I subunit NDUFB8 elicits RIP1- and RIP3-mediated necrosis. Free Radic Biol Med 2010; 48:306-17.

53. Chen CL, Chen J, Rawale S, Varadharaj S, Kaumaya PP, Zweier JL, Chen YR. Protein tyrosine nitration of the flavin subunit is associated with oxidative modification of mitochondrial complex II in the post-ischemic myocardium. J Biol Chem 2008; 283:27991-8003.

54. Klingen AR, Palsdottir H, Hunte C, Ullmann GM. Redoxlinked protonation state changes in cytochrome bc1 identified by Poisson-Boltzmann electrostatics calculations. Biochim Biophys Acta 2007; 1767:204-21.

55. Lesnefsky EJ, Hoppel CL. Cardiolipin as an oxidative target in cardiac mitochondria in the aged rat. Biochim Biophys Acta 2008; 1777:1020-7.

56. Lesnefsky EJ, Minkler P, Hoppel CL. Enhanced modification of cardiolipin during ischemia in the aged heart. J Mol Cell Cardiol 2009; 46:1008-15. 
57. Wenz T, Hielscher R, Hellwig P, Schägger H, Richers S, Hunte C. Role of phospholipids in respiratory cytochrome bc1 complex catalysis and supercomplex formation. Biochim Biophys Acta 2009; 1787:609-16.

58. Dahm CC, Moore K, Murphy MP. Persistent S-nitrosation of complex I and other mitochondrial membrane proteins by S-nitrosothiols but not nitric oxide or peroxynitrite: Implications for the interaction of nitric oxide with mitochondria. J Biol Chem 2006; 281:10056-65.

59. Brown GC, Bal-Price A. Inflammatory neurodegeneration mediated by nitric oxide, glutamate, and mitochondria. Mol Neurobiol 2003; 27:325-55.

60. Saito K, Ikeda M, Yoshioka H, Tomita T. Nitric oxide and effect of a radical scavenger N-tert-butyl- $\alpha$-phenylnitrone on stroke in a rat model. Pharmacology 2005; 73:76-80.

61. Banerjee R, Saravanan KS, Thomas B, Sindhu KM. Mohanakumar KP. Evidence for hydroxyl radical scavenging action of nitric oxide donors in the protection against 1-methyl-4-phenylpyridinium-induced neurotoxicity in rats. Neurochem Res 2008; 33:985-95.

62. Ha KS, Kim KM, Kwon YG, Bai SK, Nam WD, Yoo YM, Kim PK, Chung HT, Billiar TR, Kim YM. Nitric oxide prevents 6-hydroxydopamine-induced apoptosis in PC12 cells through cGMP-dependent PI3 kinase/Akt activation. FASEB J 2003; 17:1036-47.

63. Farinelli SE, Park DS, Greene LA. Nitric oxide delays the death of trophic factor-deprived PC12 cells and sympathetic neurons by a cGMP-mediated mechanism. J Neurosci 1996; 16:2325-34.

64. Estévez AG, Spear N, Thompson JA, Cornwell TL, Radi R, Barbeito L, Beckman JS. Nitric oxide-dependent production of cGMP supports the survival of rat embryonic motor neurons cultured with brain-derived neurotrophic factor. J Neurosci 1998; 18:3708-14.

65. Robb SJ, Connor JR. Nitric oxide protects astrocytes from oxidative stress. Ann NY Acad Sci 2002; 962:93-102.

66. Borniquel S, Valle I, Cadenas S, Lamas S, Monsalve M. Nitric oxide regulates mitochondrial oxidative stress protection via the transcriptional coactivator PGC- $1 \alpha$. FASEB J 2006; 20:1889-91.

67. Wang W, Fang H, Groom L, Cheng A, Zhang W, Liu J, Wang X, Li K, Han P, Zheng M, Yin J, Wang W, Mattson MP, Kao JP, Lakatta EG, Sheu SS, Ouyang K, Chen J, Dirksen RT, Cheng H. Superoxide flashes in single mitochondria. Cell 2008; 134:279-90.

68. Sheu SS, Wang W, Cheng H, Dirksen RT. Superoxide flashes: illuminating new insights into cardiac ischemia/reperfusion injury. Future Cardiol 2008; 4:551-4.

69. Saotome M, Katoh H, Yaguchi Y, Tanaka T, Urushida T, Satoh H, Hayashi H. Transient opening of mitochondrial permeability transition pore by reactive oxygen species protects myocardium from ischemia-reperfusion injury. Am J Physiol Heart Circ Physiol 2009; 296:H1125-32.

70. Block K, Gorin Y, Abboud HE. Subcellular localization of Nox4 and regulation in diabetes. Proc Natl Acad Sci USA 2009; 106:14385-90.

71. López LC, Escames G, Tapias V, Utrilla P, León J, AcuñaCastroviejo D. Identification of an inducible nitric oxide synthase in diaphragm mitochondria from septic mice: its relation with mitochondrial dysfunction and prevention by melatonin. Int J Biochem Cell Biol 2006; 38:267-78.

72. Harrois A, Huet $O$, Duranteau J.Alterations of mitochondrial function in sepsis and critical illness. Curr Opin Anaesthesiol 2009; 22:143-9.

73. Dungel P, Mittermayr R, Haindl S, Osipov A, Wagner C, Redl H, Kozlov AV. Illumination with blue light reactivates respiratory activity of mitochondria inhibited by nitric oxide, but not by glycerol trinitrate. Arch Biochem Biophys 2008; 471:109-15.

74. López LC, Escames G, Ortiz F, Ros E, Acuña-Castroviejo D. Melatonin restores the mitochondrial production of ATP in septic mice. Neuroendocrinol Lett 2006; 27:623-30.

75. Zhang H, Squadrito GL, Pryor WA. The reaction of melatonin with peroxynitrite: formation of melatonin radical cation and absence of stable nitrated products. Biochem Biophys Res Commun 1998; 251:83-7.

76. Zhang H, Squadrito GL, Uppu R, Pryor WA. Reaction of peroxynitrite with melatonin: A mechanistic study. Chem Res Toxicol 1999; 12:526-34.

77. Blanchard B, Pompon D, Ducrocq C. Nitrosation of melatonin by nitric oxide and peroxynitrite. J Pineal Res 2000; 29:184-92.

78. Peyrot F, Houée-Levin C, Ducrocq C. Melatonin nitrosation promoted by $\cdot \mathrm{NO}_{2}$; comparison with the peroxynitrite reaction. Free Radic Res 2006; 40:910-20.

79. Peyrot F, Fernandez BO, Bryan NS, Feelisch M, Ducrocq C. $N$-Nitroso products from the reaction of indoles with Angeli's salt. Chem Res Toxicol 2006; 19:58-67.

80. Blanchard-Fillion B, Servy C, Ducrocq C. 1Nitrosomelatonin is a spontaneous NO-releasing compound. Free Radic Res 2001; 35:857-66.

81. Peyrot F, Grillon C, Vergely C, Rochette L, Ducrocq C. Pharmacokinetics of 1-nitrosomelatonin and detection by EPR using iron dithiocarbamate complex in mice. Biochem J 2005; 387(Pt 2):473-8.

82. De Biase PM, Turjanski AG, Estrin DA, Doctorovich F. Mechanisms of NO release by $N^{1}$-nitrosomelatonin: nucleophilic attack versus reducing pathways. J Org Chem 2005; 70:5790-8.

83. Ressmeyer A-R, Mayo JC, Zelosko V, Sáinz RM, Tan D$\mathrm{X}$, Poeggeler B, Antolín I, Zsizsik BK, Reiter RJ, Hardeland R. Antioxidant properties of the melatonin metabolite $\quad N^{1}$-acetyl-5-methoxykynuramine (AMK): scavenging of free radicals and prevention of protein destruction. Redox Rep 2003; 8:205-213.

84. Hardeland R, Ressmeyer A-R, Zelosko V, Burkhardt S, Poeggeler B. Metabolites of melatonin: Formation and properties of the methoxylated kynuramines AFMK and AMK. In: Haldar C, Singh SS (eds) Recent advances in endocrinology and reproduction: evolutionary, biotechnological and clinical applications. Banaras Hindu University, Varanasi, pp 21-38, 2004.

85. Hardeland R, Backhaus C, Fadavi A, Hess M. $N^{1}$-acetyl-5methoxykynuramine contrasts with other tryptophan metabolites by a peculiar type of NO scavenging: cyclization to a cinnolinone prevents formation of unstable nitrosamines. J Pineal Res 2007; 43:104-5.

86. Backhaus $\mathrm{C}$, Rahman $\mathrm{H}$, Scheffler $\mathrm{S}$, Laatsch $\mathrm{H}$, Hardeland R. NO scavenging by 3-hydroxyanthranilic acid and 3hydroxykynurenine: N-nitrosation leads via oxadiazoles to o-quinone diazides. Nitric Oxide 2008; 19:237-44.

87. Nowak A, Rahman H, Heer C, Schueth A, Laatsch H, Hardeland R. Reactions of the melatonin metabolite $N^{1}$ acetyl-5-methoxykynuramine (AMK) with the tyrosine side-chain fragment, 4-ethylphenol. Redox Rep 2008; 13:102-8.

88. Chucharoen $\mathrm{P}$, Chetsawang B, Putthaprasart C, Srikiatkhachorn A, Govitrapong P. The presence of melatonin receptors and inhibitory effect of melatonin on hydrogen peroxide-induced endothelial nitric oxide synthase expression in bovine cerebral blood vessels. J Pineal Res 2007; 43:35-41. 
89. Park SW, Choi SM, Lee SM. Effect of melatonin on altered expression of vasoregulatory genes during hepatic ischemia/reperfusion. Arch Pharm Res 2007; 30:1619-24.

90. Sönmez MF, Narin F, Akkuş D, Ozdamar S. Effect of melatonin and vitamin $\mathrm{C}$ on expression of endothelial NOS in heart of chronic alcoholic rats. Toxicol Ind Health 2009; 25:385-93

91. Koh PO. Melatonin regulates nitric oxide synthase expression in ischemic brain injury. J Vet Med Sci 2008; 70:747-50.

92. Wang WZ, Fang XH, Stephenson LL, Baynosa RC, Khiabani KT, Zamboni WA. Microcirculatory effects of melatonin in rat skeletal muscle after prolonged ischemia. $\mathrm{J}$ Pineal Res 2005; 39:57-65.

93. Mahle CD, Goggins GD, Agarwal P, Ryan E, Watson AJ. Melatonin modulates vascular smooth muscle tone. J Biol Rhythms 1997; 12: 690-6.

94. Doolen S, Krause DN, Dubocovich ML, Duckles SP. Melatonin mediates two distinct responses in vascular smooth muscle. Eur J Pharmacol 1998; 345: 67-9.

95. Régrigny $O$, Delagrange $P$, Scalbert $E$, Atkinson $J$, Lartaud-Idjouadiene I. Melatonin improves cerebral circulation security margin in rats. Am J Physiol 1998; 275: H139-44.

96. Hardeland R, Poeggeler B. Actions of melatonin, its structural and functional analogs in the central nervous system and the significance of metabolism. Cent Nerv Syst Agents Med Chem 2007; 7:289-303.

97. Boyle JJ. Macrophage activation in atherosclerosis: pathogenesis and pharmacology of plaque rupture. Curr Vasc Pharmacol 2005; 3:63-8.

98. Murakami A, Ohigashi H. Targeting NOX, iNOS and COX-2 in inflammatory cells: chemoprevention using food phytochemicals. Int J Cancer 2007; 121:2357-63.

99. Fortin CF, McDonald PP, Fülöp T, Lesur O. Sepsis, leukocytes, and nitric oxide (NO): an intricate affair. Shock 2010; 33:344-52.

100. Mayo JC, Sainz RM, Tan D-X, Hardeland R, Leon J, Rodriguez, C, Reiter RJ. Anti-inflammatory actions of melatonin and its metabolites, $N^{1}$-acetyl- $N^{2}$-formyl-5methoxykynuramine (AFMK) and $N^{1}$-acetyl-5methoxykynuramine (AMK), in macrophages. J Neuroimmunol 2005; 165:139-49.

101. Kelly RW, Amato F, Seamark RF. N-Acetyl-5-methoxy kynurenamine, a brain metabolite of melatonin, is a potent inhibitor of prostaglandin biosynthesis. Biochem Biophys Res Commun 1984; 121:372-9.

102. Crespo E, Macías M, Pozo D, Escames G, Martín M, Vives F, Guerrero JM, Acuña-Castroviejo D. Melatonin inhibits expression of the inducible NO synthase II in liver and lung and prevents endotoxemia in lipopolysaccharide-induced multiple organ dysfunction syndrome in rats. FASEB $\mathrm{J}$ 1999; 13:1537-46.

103. Crespo E, Macías M, Pozo D, Escames G, Martín M, Vives F, Guerrero JM, Acuña-Castroviejo D. Melatonin counteracts lipopolysaccharide-induced expression and activity of mitochondrial nitric oxide synthase in rats. FASEB J 2003; 17:932-4

104. Escames G, López LC, Ortiz F, Ros E, Acuña-Castroviejo D. Age-dependent lipopolysaccharide-induced iNOS expression and multiorgan failure in rats: effects of melatonin treatment. Exp Gerontol 2006; 41:1165-73.

105. Acuña-Castroviejo $D$, Escames $G$, León J, Carazo A, Khaldy H. Mitochondrial regulation by melatonin and its metabolites. Adv Exp Med Biol 2003; 527:549-57.

106. Tapias V, Escames G, López LC, López A, Camacho E, Carrión MD, Entrena A, Gallo MA, Espinosa A, Acuña-
Castroviejo D. Melatonin and its brain metabolite $N^{1}$ acetyl-5-methoxykynuramine prevent mitochondrial nitric oxide synthase induction in parkinsonian mice. J Neurosci Res 2009; 87:3002-10.

107. León J, Macías M, Escames G, Camacho E, Khaldy H, Martín M, Espinosa A, Gallo MA, Acuña-Castroviejo D. Structure-related inhibition of calmodulin-dependent neuronal nitric-oxide synthase activity by melatonin and synthetic kynurenines. Mol Pharmacol 2000; 58:967-75.

108. Acuña-Castroviejo D, Escames G, López LC, Hitos AB, León J. Melatonin and nitric oxide: two required antagonists for mitochondrial homeostasis. Endocrine 2005; 27:159-68.

109. Entrena A, Camacho ME, Carrión MD, López-Cara LC, Velasco G, León J, Escames G, Acuña-Castroviejo D, Tapias V, Gallo MA, Vivó A, Espinosa A. Kynurenamines as neural nitric oxide synthase inhibitors. J Med Chem 2005; 48:8174-81.

110. León J, Escames G, Rodríguez MI, López LC, Tapias V, Entrena A, Camacho E, Carrión MD, Gallo MA, Espinosa A, Tan DX, Reiter RJ, Acuña-Castroviejo D. Inhibition of neuronal nitric oxide synthase activity by $N^{1}$-acetyl-5methoxykynuramine, a brain metabolite of melatonin. $\mathrm{J}$ Neurochem 2006; 98:2023-33.

111. Silverman RB. Design of selective neuronal nitric oxide synthase inhibitors for the prevention and treatment of neurodegenerative diseases. Acc Chem Res 2009; 42:43951.

112. Clément $P$, Gharib A, Cespuglio R, Sarda N. Changes in sleep-wake cycle architecture and cortical nitric oxide release during ageing in the rat. Neuroscience 2003; 116:863-70

113. Tunçtan B, Weigl Y, Dotan A, Peleg L, Zengil H, Ashkenazi I, Abacioğlu N. Circadian variation of nitric oxide synthase activity in mouse tissue. Chronobiol. Int. 2002; 19:393-404.

114. León J, Acuña-Castroviejo D, Escames G, Tan DX, Reiter RJ. Melatonin mitigates mitochondrial malfunction. J Pineal Res 2005; 38:1-9.

115. Srinivasan V, Pandi-Perumal SR, Maestroni GJM, Esquifino AI, Hardeland R, Cardinali DP. Role of melatonin in neurodegenerative diseases. Neurotox Res 2005; 7:293-318.

116. Srinivasan V, Pandi-Perumal SR, Cardinali DP, Poeggeler B, Hardeland R. Melatonin in Alzheimer's disease and other neurodegenerative disorders. Behav Brain Funct 2006; 2:15.

117. Morais VA, De Strooper B. Mitochondria dysfunction and neurodegenerative disorders: cause or consequence. J Alzheimers Dis 2010; 20 Suppl 2:S255-63.

118. Di Filippo M, Chiasserini D, Tozzi A, Picconi B, Calabresi $\mathrm{P}$. Mitochondria and the link between neuroinflammation and neurodegeneration. J Alzheimers Dis 2010; 20 Suppl 2:S369-79.

119. Wang $X$, Michaelis EK. Selective neuronal vulnerability to oxidative stress in the brain. Front Aging Neurosci 2010; 2:12.

120. Ma J, Shaw VE, Mitrofanis J. Does melatonin help save dopaminergic cells in MPTP-treated mice? Parkinsonism Relat Disord 2009; 15:307-14

121. Carretero M, Escames G, López LC, Venegas C, Dayoub JC, García L, Acuña-Castroviejo D. Long-term melatonin administration protects brain mitochondria from aging. $\mathrm{J}$ Pineal Res 2009; 47:192-200.

122. Okatani Y, Wakatsuki A, Reiter RJ. Melatonin protects hepatic mitochondrial respiratory chain activity in senescence-accelerated mice. J Pineal Res 2002; 32:143-8. 
123. Zhou JL, Zhu XG, Ling YL, Li Q. Melatonin reduces peroxynitrite-induced injury in aortic smooth muscle cells. Acta Pharmacol Sin 2004; 25:186-90.

124. Kesik V, Guven A, Vurucu S, Tunc T, Uysal B, Gundogdu G, Oztas E, Korkmaz A. Melatonin and 1400W ameliorate both intestinal and remote organ injury following mesenteric ischemia/reperfusion. J Surg Res 2009; 157:e97-105.

125. Tengattini S, Reiter RJ, Tan DX, Terron MP, Rodella LF, Rezzani R. Cardiovascular diseases: protective effects of melatonin. J Pineal Res 2008; 44:16-25.

126. Dominguez-Rodriguez A, Abreu-Gonzalez P, Reiter RJ. Clinical aspects of melatonin in the acute coronary syndrome. Curr Vasc Pharmacol 2009; 7:367-73.

127. Murawska-Cialowicz E, Januszewska L, Zuwala-Jagiello J, Milczarska J, Zawadzki M, Paprocka-Borowicz M, Wierzbicka-Damska I. Melatonin decreases homocysteine level in blood of rats. J Physiol Pharmacol 2008; 59:71729.
128. Aladag MA, Turkoz Y, Parlakpinar H, Ozen H, Egri M, Unal SC. Melatonin ameliorates cerebral vasospasm after experimental subarachnoidal haemorrhage correcting imbalance of nitric oxide levels in rats. Neurochem Res 2009; 34:1935-44.

129. Tailleux A, Torpier G, Bonnefont-Rousselot D, Lestavel S, Lemdani M, Caudeville B, Furman C, Foricher R, GardesAlbert M, Lesieur D, Rolando C, Teissier E, Fruchart JC, Clavey V, Fievet C, Duriez P. Daily melatonin supplementation in mice increases atherosclerosis in proximal aorta. Biochem Biophys Res Commun 2002; 293:1114-23

130. Smith MA, Richey Harris PL, Sayre LM, Beckman JS, Perry G. Widespread peroxynitrite-mediated damage in Alzheimer's disease. J Neurosci 1997 17:2653-7.

131. Hensley K, Maidt ML, Yu Z, Sang H, Markesbery WR, Floyd RA. Electrochemical analysis of protein nitrotyrosine and dityrosine in the Alzheimer brain indicates regionspecific accumulation. J Neurosci 1998; 18:8126-32. 